\title{
Problem određivanja složenih (objektivnih i subjektivnih) indeksa kao cjelovitih mjera kvalitete života
}

\section{Lana Slavuj}

Prirodoslovno-matematički fakultet, Geografski odsjek, Sveučilište u Zagrebu, Hrvatska e-mail: lslavuj@geog.pmf.hr

\begin{abstract}
SAŽETAK U radu se raspravlja o problematici određivanja složenih (objektivnih i subjektivnih) indeksa kao cjelovitih mjera kvalitete života. Integracija velikoga broja pokazatelja u jedan indeks intrigantna je ideja koja čini važan dio istraživanja kvalitete života. Temelji se na pretpostavci da ljudi ne izoliraju pojedine aspekte svojih života, nego posjeduju jedinstven osjećaj zadovoljstva životom. No, to je ujedno i jedna od najkontroverznijih pojedinosti koje se vežu uz ovakva istraživanja jer su načini na koje se složeni indeksi određuju podložni brojnim kritikama. Istraživanja problematike pokazuju da nije jednostavno konstruirati jedinstveni indeks koji će biti dovoljno cjelovit da nedvosimisleno uključuje sve aspekte individualne ili kolektivne kvalitete života. Iako se složeni indeksi kvalitete života često primijenjuju (pogotovo za iskazivanje stanja na razini pojedinih država i za usporedbe među njima), dosadašnja iskustva pokazuju da ih je primjerenije zamijeniti neagregiranim skupovima objektivnih podataka ili izravnim pitanjem pojedincima o njihovoj ukupnoj kvaliteti života.
\end{abstract}

Ključne riječi: indeksi kvalitete života, objektivni pokazatelji, subjektivni pokazatelji, ponderiranje pokazatelja.

\section{Uvod}

U istraživanju koncepta kvalitete života primjenjuju se objektivni i subjektivni pokazatelji. Objektivni pokazatelji odražavaju objektivna stanja i promjene neovisno o osobnim evaluacijama, a subjektivni pokazatelji naglašavaju individualnu percepciju i evaluaciju, te ukazuju do koje su razine ispunjena subjektivna očekivanja pojedinca. Posebno intrigantna ideja, koja čini važan dio istraživanja kvalitete života, problematika je integracije velikoga broja pokazatelja u jedan indeks, odnosno redukcija ovoga iznimno kompleksnoga fenomena na jednu brojku. Temelji se na pretpostavci da ljudi ne izoliraju pojedine aspekte svojih života, nego ih kombiniraju u ukupno iskustvo života. Također, motivacija za razvoj složenih indeksa proizašla je iz potrebe da se koncizno odgovori na jedno od temeljnih pitanja - kako neki prostor napreduje u pogledu socijalnih uvjeta tijekom vremena, kao i u usporedbi s drugim prostornim cjelinama. 
No, sažimanje različitih pokazatelja u jedinstven indeks jedna je od najosporovanijih i najkontroverznijih pojedinosti koje se vežu uz istraživanja kvalitete života. Razlog tomu su načini na koji se podaci sažimaju u indeks. Naime, iako se mnogo koriste u istraživanjima, agregacijske su tehnike podložne brojnim kritikama. Pitanje agregacije objektivnih i subjektivnih pokazatelja jedan je od najvećih problema oko kojega se rasprave vode još od 1960-ih. Općenito, te su rasprave podijelile autore istraživanja na one koji se zalažu za agregaciju pokazatelja u jedan indeks i na one koji zagovaraju neagregirane skupove pokazatelja.

Ipak, činjenica je da se složeni indeksi vrlo često primjenjuju u analizama i prezentaciji rezultata istraživanja kvalitete života. Do danas su razvijeni brojni indeksi blagostanja i to na svim razinama, od nacionalnih, regionalnih do lokalnih. Kao primjer mogu se navesti sljedeći: Index of Social Health (Institute for Innovation in Social Policy, 2013.), Quality of Life Index (UIC, 2013.), Social Progress Index (The Social Progress Imperative, 2013.), Genuine Progress Indicator (Genuine Progress, 2013.), Index of Human Progress (Emes i Hahn, 2001.), Human Development Index (UNDP, 2013.), Better Life Index (OECD, 2013.), Gini Index (The World Bank, 2013.), Economist Intelligence Unit's Quality-of-life Index (Economist Intelligence Unit, 2013.) i brojni drugi. Mnogi od navedenih indeksa kombinacija su jednih i drugih pokazatelja, čime se nastoji obuhvatiti složenost koncepta. U cilju što boljega razumijevanja kvalitete života primjereno je koristiti obje vrste pokazatelja jer niti jedan tip mjera sam po sebi nije potpun, a i svaki od njih zahvaća različite aspekte kvalitete života.

Svrha ovoga rada jest pružanje detaljnoga pregleda problema i nedoumica s kojima se istraživači susreću prilikom određivanja indeksa kvalitete života, a u cilju što boljega razumijevanja i pojašnjenja navedene problematike. Brojna istraživanja primjenjuju indekse kvalitete života, no pritom ih se tek mali broj kritički osvrće na nedostatke i poteškoće koje proizlaze iz konstrukcije jedinstvenih pokazatelja. Objektivni i subjektivni pokazatelji različite su mjere pa su i problemi koji nastaju prilikom njihove integracije drugačije prirode. Stoga je u radu taj problem obrađen odvojeno, odnosno najprije su raspravljena pitanja vezana uz deriviranje indeksa koji nastaju na temelju objektivnih pokazatelja, a potom indeksa na temelju subjektivnih pokazatelja.

\section{Indeksi temeljeni na objektivnim pokazateljima}

Smith (1973.) je još u 1970-ima dobro sažeo bit problema agregacije objektivnih pokazatelja. Naime, konstrukcija složenoga indeksa podrazumijeva tzv. spajanje nespojivoga jer se sumiraju različiti pokazatelji, npr. smrtnosti dojenčadi i broja krađa automobila. U ekonomskom izračunavanju indeksa postoji zajednički nazivnik, poput dolara ili neke druge valute, što u primjeru kvalitete života ne može biti slučaj. Koncept kvalitete života uključuje mnoge dimenzije, tako da ne postoji jednostavan i potpuno opravdan način za pribrojavanje "mrtve dojenčadi, psihopata i ukradenih automobila" (Smith, 1973.:60). Problem integracije različitih aspekata kvalitete života, koji se pojavljuju u različitim mjernim jedinicama, moguće je statistički riješiti tehnikama standardizacije vrijednosti pokazatelja (npr. pomoću Z-vrijednosti). No, pritom još uvijek ostaje neriješeno pitanje relativne vrijednosti pojedinih pokazatelja 
za ukupnu kvalitetu života. Naime, može se pretpostaviti da nisu svi aspekti koje uključuje koncept kvalitete života za sve ljude jednako važni.

Stoga, iako je ideja primjene jednostavnih surogata za složene koncepte privlačna, jer donekle olakšava razumijevanje koncepta, agregacija pokazatelja u jedan indeks ne mora nužno predstavljati i najbolje rješenje. Konstrukcijom složenih indeksa mogu se izgubiti mnogi vrijedni podaci iz originalnoga skupa podataka, pa postoji mogućnost donošenja pogrešnih zaključaka (Pacione, 1982.). Van de Ven, Kazemier i Keuning (1999.) također kritiziraju agregaciju i smatraju da treba napustiti pristup koji se temelji na jednom pokazatelju. Argumentiraju da je socijalno blagostanje višedimenzionalan fenomen, pa je agregacija njegovih mnogih i, međusobno različitih aspekata, zapravo nemoguća. Osim toga, ističu da jedan ukupan pokazatelj ne može biti relevantan za politike, a upravo bi to trebao biti glavni zadatak proučavanja blagostanja u društvu. Umjesto jednoga složenoga pokazatelja, potrebni su mnogi koji će se odnositi na različita područja upravljanja društvom (ekonomska politika, socijalna politika, okolišna politika i dr.).

S druge strane, zagovornici složenih indeksa kvalitete života smatraju da je agregacija pokazatelja, ne samo moguća, nego i poželjna, te da je taj postupak nužan element znanstvenoga pristupa u procesu razumijevanja koncepta. Indeksi mogu vrlo dobro ukazivati na promjene u trendovima promatranoga fenomena. Primjerice, pad vrijednosti indeksa može upućivati da postoji određeni problem, a na istraživačima ili donosiocima odluka je da detaljnije istraže u kojem se segmentu koncepta pojavio i koje je akcije potrebno poduzeti (Sharpe, 1999.).

Moguće je razlučiti dva generalna pristupa koja se primjenjuju u agregaciji objektivnih pokazatelja u indeks kvalitete života:

1. svi odabrani pokazatelji jednako su vrijedni za koncept kvalitete života

2. odabrani pokazatelji razlikuju se po važnosti za koncept kvalitete života te je nužno definirati njihove relativne vrijednosti (pondere).

Slika 1.

Shematski prikaz mogućih manipulacija objektivnih pokazatelja u složeni indeks kvalitete života

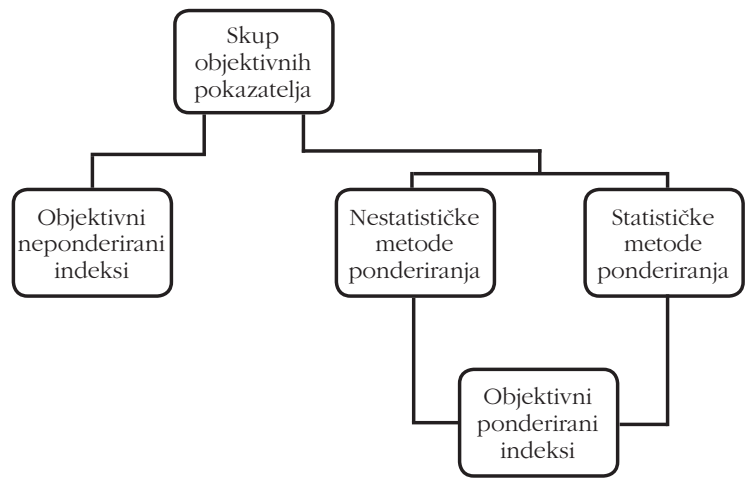




\subsection{Indeksi temeljeni na jednako vrijednim objektivnim pokazateljima}

Prvi pristup, dakle, podržava ideju da su svi pokazatelji odabrani u skup jednako vrijedni za koncept kvalitete života. Na tom je principu 1990. u sklopu UN-ova programa za razvoj (UNDP) razvijen Human Development Index (HDI), koji uspoređuje i rangira države svijeta, te ih dijeli na: razvijene zemlje, zemlje u razvoju i nerazvijene zemlje. Indeks čine tri dimenzije koje predstavljaju važna područja ljudskoga razvoja: 1) dug i zdrav život, 2) znanje, 3) standard života. UNDP pod razvojem podrazumijeva proces povećavanja mogućnosti koje ljudi imaju na raspolaganju, te smatraju da ga ove tri dimenzije dobro opisuju. Ako navedene mogućnosti nisu dostupne, onda će i mnoge druge ostati neispunjene (HDR, 1993.). Pokazatelji koji predstavljaju navedene dimenzije su: očekivana životna dob pri rođenju, razina pismenosti kod odraslih te bruto domaći proizvod po glavi stanovnika prilagođen kupovnoj moći. No, HDI je vrlo brzo nakon pojavljivanja doživio kritike iz više razloga. Jedna od njih tiče se istih vrijednosti koje nose ova tri pokazatelja za ukupan koncept (Smith, 1996.). Također, zamjera mu se što ne uzima u obzir okolišna pitanja koja danas čine okosnicu mnogih razvojnih programa.

Također, brojni samostalni istraživači na ovom principu agregiraju pokazatelje u indeks kvalitete života. Primjerice, jednu od prvih takvih studija kvalitete života, koja je imala veliki utjecaj na kasnija slična istraživanja, proveo je Liu (1976.) u 243 metropolitanskih područja SAD-a, pri čemu je uključio 123 objektivna pokazatelja u ukupan indeks. Autor je smatrao da je jednako bodovanje pokazatelja jednostavnije i bolje. Pogotovo, s obzirom na činjenicu da postoji još manji konsenzus oko pitanja koji pokazatelj koliko vrijedi za koncept, nego oko često postavljanoga pitanja o tome koji je definitivni popis domena koje čine koncept kvalitete života (Pacione, 1982.). Istraživanja koja se bave kvalitetom života unutar jedne države, vjerojatno su ipak manje podložna problemima definiranja pondera, nego ona istraživanja koje karakteriziraju međunarodne usporedbe. Naime, podaci za različite dijelove iste države vjerojatno su prikupljeni na temelju istih principa i definicija, te sa sličnom razinom točnosti. Također, za pretpostaviti je da postoji konsenzus na razini države oko sastavnica dobroga života, za razliku od međunarodnih usporedba gdje se kontrastiraju i države koje imaju sasvim drugačije kulturne tradicije i vrijednosne obrasce, pa je manje logično očekivati da aspekti koncepta imaju jednake vrijednosti (Smith, 1996.).

Općenito govoreći, glavne prednosti derivacije indeksa na principu jednako vrijednih, neponderiranih pokazatelja, su: lakša interpretacija rezultata (jer ne uključuju složene statističke analize) te financijska i vremenska manja zahtjevnost (jer ne uključuju, primjerice, skupa anketna istraživanja). Ipak, jednostavnost je i njihov nedostatak jer je malo vjerojatno da svi pokazatelji kvalitete života imaju za sve ljude jednaku vrijednost. 


\subsection{Indeksi temeljeni na objektivnim pokazateljima koji nose različite vrijednosti za koncept}

Drugi pristup agregacije skupa objektivnih pokazatelja u složeni indeks polazi od pretpostavke da važnost pojedinih pokazatelja varira među grupama ljudi, odnosno da su neki aspekti života više važni, a drugi imaju puno manji utjecaj na stvaranje ukupnoga osjećaja zadovoljstva životom. Stoga je potrebno odrediti koje su relativne vrijednosti ili ponderi pokazatelja uključenih u koncept. Najvažnije pitanje pritom jest na koji način saznati koja je važnost pojedinoga pokazatelja.

Općenito, moguće je izdvojiti dva glavna pristupa koja se u istraživanjima primjenjuju za definiranje pondera pokazatelja: nestatističke metode i statističke metode (tablica 1.). U nestatističke metode određivanja pondera pokazateljima mogu se uvrstiti: samostalne procjene autora istraživanja, mišljenje stručnjaka, literatura posvećena istoj ili sličnoj problematici te istraživanja javnoga mnijenja putem anketa ili fokusnih grupa. Najprimjenjivanije statističke metode određivanja pondera su analiza regresije i faktorska analiza (Wong, 2006.; Malkina-Pykh i Pykh, 2008.; Eyles, 1994.).

Najveća prednost nestatističkih metoda definiranja vrijednosti pokazatelja jest to što su jednostavne i lako razumljive. Naime, načini na koji su ponderi određeni mogu se jasno prepoznati i time biti otvoreni za širu raspravu i kritiku, ukoliko je potrebno (Wong, 2006.). No, jednostavniji način ne mora uvijek biti najsretniji izbor, pogotovo stoga što su nestatističke metode prožete arbitrarnim i subjektivnim prosudbama. Primjerice, teško je odrediti vrijednost pokazateljima koji se odnose na ekonomski razvoj ili na zagađenje okoliša, kada je ekonomski napredak važan za kvalitetu života, ali s druge strane može imati negativan utjecaj na prirodni okoliš, koji je također njen značajan aspekt. Takve subjektivne nedoumice nastoje se izbjeći primjenom objektivnih statističkih metoda. Međutim, njihov veliki nedostatak je kompliciranost i složenost, što cijeli postupak ponderiranja čini manje transparentnim i razumljivim (Wong, 2006.).

Tablica 1.

Dva glavna pristupa u definiranju vrijednosti (pondera) objektivnih pokazatelja

\begin{tabular}{|c|c|}
\hline Nestatističke metode & Statističke metode \\
\hline Procjena istraživača & Analiza regresije \\
Mišljenje stručnjaka & Faktorska analiza \\
Literatura & \\
Anketna istraživanja i fokus grupe & \\
\hline
\end{tabular}

Izvor: Wong, 2006.; Eyles, 1994.; Malkina-Pykh i Pykh, 2008.

Svaki od navedenih načina definiranja vrijednosti pondera razmotren je detaljnije. Autori studija prema vlastitom nahođenju i procjeni mogu određivati pondere po- 
jedinim dimenzijama koncepta kvalitete života. Međutim, na taj način, kako kažu kritičari, nisu dobili kvalitetu života onako kako je vide stanovnici analiziranih područja, nego svoju vlastitu. Također, time se zanemaruje činjenica da se kvaliteta života može u istom prostoru razlikovati s obzirom na različite socijalne grupe. Primjerice, ako je jedan od pokazatelja kvalitete života u gradu broj dobrib restorana, postavlja se pitanje što to znači za stanovnike slaboga materijalnog statusa. Možda je za određenu studiju korisno prikupiti podatak o brojnom, objektivnom stanju restorana u gradu, no većina znanstvenika slaže se da je još važnije značenje tih objektivnih uvjeta koje im pripisuju sami stanovnici. Jesu li ti restorani zaista dobri prema kriterijima ljudi koji žive u njihovoj blizini, koliko često ih posjećuju te koliko je taj element uopće važan, odnosno pridonosi li njihovoj ukupnoj kvaliteti života (Marans i Couper, 2000.). Drugim riječima, ukoliko istraživači sami definiraju pondere, onda proizašli rezultati više reflektiraju njihove osobne preferencije i predrasude, nego kvalitetu života stanovnika.

Vrijednosti pokazatelja mogu se odrediti i na temelju mišljenja stručnjaka za pojedinu domenu (Malkina-Pykh i Pykh, 2008.). Prednost ovoga načina jest što se u analizu integrira praktično iskustvo profesionalaca koji se tim područjem bave. Međutim, ponekad je teško odrediti tko su najbolji stručnjaci za pojedinu domenu, a nedostatak je i što se u istraživanje mogu uplesti osobne vrijednosti, profesionalni interesi i pristranost (Wong, 2006.), odnosno "profesionalni imperijalizam" (Smith, 1996.).

Vrijednosti pokazatelja mogu biti izvučeni iz literature na temelju prijašnjih sličnih studija. Međutim, malo je vjerojatno da već postoji istraživanje koje pokriva potpuno iste ključne teme kao neka druga studija, pogotovo u slučaju kvalitete života koju karakterizira nekohezivnost u definiranju i mnogi različiti načini mjerenja (Wong, 2006.).

Anketnim istraživanjem moguće je saznati važnost pojedinih pokazatelja za danu populaciju. No, takva vrsta istraživanja zahtijeva velike materijalne troškove i vremenski je zahtjevna. Morris, Findlay i Rogerson (1988.) proveli su studiju kvalitete Života u britanskim gradovima kombinirajući subjektivne i objektivne pokazatelje. Ispitanici $(\mathrm{N}=1400)$ su na skali od 1 do 5 određivali važnost svakoga od 20 elemenata izabranih da prezentiraju koncept kvalitete života. Prosjek njihovih odgovora činio je pondere koji su kasnije pridodani objektivnim podacima prikupljenim u 38 najvećih britanskih gradova u konstrukciji indeksa kvalitete života. Autori ističu da je posebno važan i indikativan rezultat njihovoga istraživanja činjenica što su socijalni i okolišni aspekti kvalitete života visoko rangirani po važnosti. Pogotovo stoga što brojne studije, koje uspoređuju regije ili gradove, primjenjuju ekonomske pokazatelje kao najvažnije aspekte kvalitete života, a što u kontekstu ovoga njihovog rezultata nikako nije opravdano.

Fokus grupe obuhvaćaju manji broj ispitanika i nisu toliko vremenski i materijalno zahtjevne. Sharpe (1999.) ističe da su anketna istraživanja i fokus grupe najprihvatljiviji načini za određivanje pondera pokazatelja. Moguća je i kombinacija spomenutih metoda, primjerice mišljenje stručnjaka, te fokus grupe koju čine neprofesionalci (građani) (Lofti i Solaimani, 2009.). 
Spomenuto je da su najčešće primjenjivane statističke metode za određivanje pondera analiza regresije i faktorska analiza. Vrijednosti pojedinih pokazatelja (nezavisne varijable) mogu se odrediti na temelju njihovoga doprinosa u objašnjavanju jedne mjere (zavisne varijable) u sklopu analize regresije. Regresijski koeficijent svake nezavisne varijable omogućava automatsko ponderiranje zavisne varijable koju objašnjava. Najveći nedostatak ove metode jest u pronalaženju jedinstvene varijable koja dovoljno dobro predstavlja cijeli koncept (Wong, 2006.; van Poll, 1997.).

Faktorska analiza koristi se za identifikaciju relativno maloga broja faktora unutar većega skupa varijabli. Prednost ove metode jest da dobiveni faktori olakšavaju razumijevanje općega koncepta na temelju empirijskih veza sa skupom pokazatelja. Također, faktorska analiza omogućava automatsko statističko ponderiranje svake varijable u faktoru. Dobivene faktorske vrijednosti (bodovi) mogu biti korišteni kao ponderi. Ipak, faktorska analiza ima i svoje nedostatke. Aplikacija faktorske analize uključuje neke kritične odluke, kao npr. koje statističke mogućnosti koristiti u statističkim procedurama te koliko faktora treba biti primijenjeno. Nadalje, faktori se često sastoje od nekoliko varijabli čije značenje za kvalitetu života nije uvijek jednoznačno. Zbog toga je potrebna subjektivna procjena istraživača za određivanje predznaka faktora, odnosno utječu li pozitivno ili negativno na ukupnu kvalitetu života. Ambivalentnost značenja faktora je veliki problem u korištenju faktorske analize za računanje složenih indeksa. Proces određivanja naziva svakom faktoru prema njegovim atributima također je subjektivan proces. Faktorska analiza je usprkos navedenim nedostacima često korištena metoda za definiranje pondera pokazatelja (Li i Weng, 2007.; Sereke Tesfazghi, 2009.; Zebardast, 2009.; Das, 2008.; Sharpe, 1999.; Hasan, 2007.; Hagetry i sur., 2001.).

Navedene metode prikupljanja informacija o tome koliko pojedini pokazatelj vrijedi za ukupnu kvalitetu života, ne iscrpljuju sve mogućnosti, ali predstavljaju neke od najprimjenjivanijih metoda u istraživanjima. Njihovi nedostaci ukazuju na činjenicu da je konstrukcija objektivnih indeksa kvalitete života problematična i da nije pronađeno jedinstveno zadovoljavajuće rješenje. Dodjeljivanje pondera objektivnim pokazateljima nužno uključuje manju ili veću dozu subjektivnosti, ovisno o načinu na koji se oni izvode. Neponderiranim indeksima zamjera se jednako vrednovanje svih komponenata. Očigledno je da nije lako sažeti kompleksnu realnost na jednu brojku koja će biti sveobuhvatna i nedvosmisleno ukazivati gdje je kvaliteta života bolja ili lošija.

Prema nekim autorima (npr. Sawicki i Flynn, 1996.) složeni su indeksi prikladniji za pregledan prikaz stanja na višim prostornim razinama (npr. država), no nisu odgovarajući za analiziranje problematike na nižim razinama prostorne hijerarhije (lokalna razina). Osim toga, kako je već spomenuto, primjena složenih indeksa podrazumijeva redukciju inicijalnoga skupa podataka, što može dovesti do prikrivanja detaljnijih informacija o različitim aspektima kvalitete života. Očigledno, nije jednostavno konstruirati jedinstveni indeks koji bi bio potpuno cjelovit i uključivao sve aspekte individualne ili kolektivne kvalitete života (Massam, 2002.). 
Također, vrlo je često krajnji cilj konstrukcije indeksa, rangiranje i formiranje tablica najboljih i najlošijih prostornih entiteta prema kvaliteti života, poput primjerice knjige Places Rated Almanac: The Classic Guide for Finding Your Best Places to Live in America. Knjiga je tipičan predstavnik studija rangiranja gradova koje su medijski vrlo popularne. Naime, rangiranja gradova prema indeksima kvalitete života redovito provode i objavljuju časopisi: The Economist, The Money Magazine, Asia Week, The Fortune Magazine ili internetske stranice poput Mercer Global Quality of Living City Rankings. Ovakve studije predstavljaju jednostavan i popularan pristup kvaliteti života kojima je jednako važno informirati javnosti o tome gdje je najbolje živjeti, zaposliti se, otići na odmor, kupiti nekretninu i sl., kao i zabaviti publiku. Njihov komercijalni uspjeh pokazuje da postoji veliko zanimanje publike za temu kvalitete života pa se od 1990-ih rezultati ovakvih studija sve više koriste i u sklopu marketinških promocija gradova (Hasan, 2007.; Rogerson, 1999.). Koliko je relativna vjerodostojnost takvih indeksa, priznaju i sami autori knjige Places Rated Almanac pa u novijim izdanjima ostavljaju mogućnost da čitatelji sami, prema svojim preferencijama, dodaju pondere i računaju indekse (Savageau, 2007.).

\subsection{Alternativni pristup analiziranja i prikazivanja objektivnih pokazatelja kvalitete života}

Postoje i drugačiji načini pojednostavljivanja strukture pokazatelja i njihovoga prikazivanja od sažimanja pokazatelja u indeks. U literaturi se u te svrhe navode opisni profili prostornih cjelina, skupovi reprezentativnih pokazatelja i višedimenzionalne prezentacijske metode.

Jedan od mogućih načina jest identifikacija prostora prema skupu varijabli koje čine operacijsku definiciju koncepta. Ovaj način predlagao je još Knox (1978.), a njegova prednost je da dolazi do manjega gubitka informacija nego s agregacijskim pristupima, što ga odlikuje većom osjetljivošću za višedimenzionalnost konstrukta. Navedeni pristup podrazumijeva povezivanje određenoga broja pokazatelja, koji odražavaju iste ili slične aspekte proučavanoga fenomena, u skupove, a može se izvesti primjenom multivarijantnih analiza, kao što su faktorska ili klaster analiza. Spomenute analize mogu rezultirati prostornim obrascima ili opisnim profilima prostornih cjelina koje naknadno mogu poslužiti kao okvir za daljnje, detaljnije analize (primjerice anketna istraživanja). Wong (2006.) smatra da je bit primjene pokazatelja upravo u naglašavanju i korištenju njihove analitičke snage, a ne samo njihova tehnička sinteza.

Sljedeća mogućnost pojednostavljivanja strukture skupa pokazatelja je izdvajanje pojedinih ključnih, reprezentativnih pokazatelja (eng. key/headline/flagship indicators) (van de Ven i sur., 1999.). Njihova primjena omogućava balans između osiguravanja dovoljne količine informacija te potrebe za što jednostavnijim načinom prikazivanja prikupljenih podataka. Ni u ovom slučaju ne postoji jedinstveno primjenjiv koncept izbora takvih ključnih pokazatelja. Većinom se izabiru na temelju subjektivnih procjena istraživača prema glavnim ciljevima istraživanja ili uz pomoć statističkih metoda (poput korelacijske analize kojom se mogu izdvojiti oni pokazatelji što jako 
koreliraju s drugima te mjere iste aspekte promatranoga fenomena) (Wong, 2006.). Primjerice, UN-ovi pokazatelji za održivi razvoj (United Nations Indicators of Sustainable Development, 2007.) predstavljeni su s 50 ključnih pokazatelja, iako se cijeli skup sastoji od 96 pokazatelja. OECD (2008.) primjenjuje 10-13 ključnih okolišnih pokazatelja, dok se cijeli skup sastoji od ukupno 40-50 okolišnih pokazatelja.

Pri prezentaciji odabranih ključnih pokazatelja moguće je primijeniti višedimenzionalne dijagrame za prikaz pokazatelja, čime se naglašavaju vrijednosti više reprezentativnih pokazatelja umjesto da se ističe samo jedan ukupan. Primjer takvih višedimenzionalnih prezentacijskih metoda su radijalni dijagrami (Wong, 2006.). Vrijednost pojedinih pokazatelja raspoređuju se duž radijalnih osi od kojih svaka predstavlja pojedini pokazatelj. Uključene su minimalne i maksimalne vrijednosti. Ovakav način primijenili su, primjerice, Kenji, Masanobu i Hitomi (2008.) za prikazivanje i uspoređivanje performansi po pet ključnih domena u japanskom gradu Takamatsu (ekonomski potencijali, kulturne i opskrbne mogućnosti, sigurnost, stanje okoliša) na njegovoj periferiji i u centru. Radijalne dijagrame primijenila je i Azijska banka za razvoj kako bi mogla pratiti i uspoređivati stanje u nekoliko gradova prema određenom spektru pokazatelja (Wong, 2006.). Navedena metoda prezentacije primjenjuje se i za prikaz rezultata dobivenih subjektivnim pokazateljima.

\section{Indeksi temeljeni na subjektivnim pokazateljima}

Rasprava je do sada bila posvećena problematici konstrukcije indeksa nastalih na temelju objektivnih pokazatelja. Objektivni pokazatelji inherentno ne sadržavaju komponentu subjektivne važnosti pa se debate vode je li im uopće potrebno i na koje načine najefikasnije moguće naknadno pridružiti pondere. U tu svrhu navedene su najčešće korištene metode te njihove prednosti i nedostaci, kao i rasprava je li konstrukcija subjektivnih indeksa nužna i na koji način se treba provoditi.

I subjektivni indeksi mogu se podijeliti u dvije kategorije. Jedni nastaju sumiranjem jednako vrijednih pokazatelja, a drugi sumiranjem pokazatelja koji nose različite vrijednosti za ukupan koncept (slika 2.).

Slika 2.

Shematski prikaz mogućih manipulacija subjektivnih pokazatelja u složeni indeks

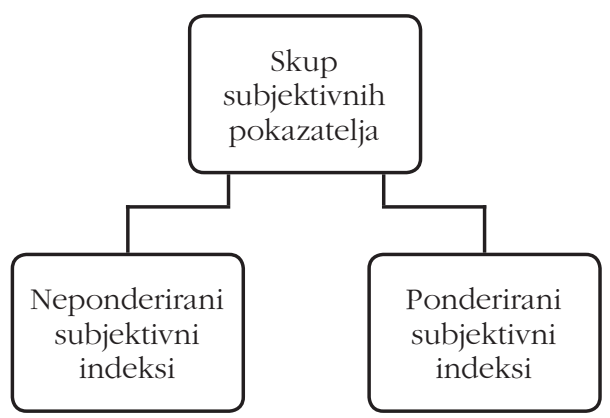

Izvor: autorica 
Primjer indeksa koji uvažava subjektivno iskustvo kvalitete života, a koji nastaje sumiranjem pokazatelja jednakih vrijednosti jest Australian Unity Wellbeing Index. Indeks se temelji na prosječnim vrijednostima zadovoljstva s pojedinim aspektima osobnoga života (zdravlje, osobne veze, osjećaj sigurnosti, standard života, postignuća u životu, osjećaj pripadnosti zajednici i buduća sigurnost) i nacionalnoga Života Australije (socijalni uvjeti, ekonomska situacija, stanje okoliša, gospodarstvo, sigurnost i vlada) (Australian Unity, 2013.).

No, debate oko konstrukcije subjektivnih indeksa uključuju i pitanja o važnosti pojedinih domena za koncept. O kvaliteti života uobičajeno se promišlja kao o globalnom, cjelovitom konstruktu koji se sastoji od mnogo specifičnih domena. Slijedom ideje da pojedine domene nisu jednako važne svim ljudima, u brojne instrumente za mjerenje kvalitete života su uz pitanja o zadovoljstvu domenama, uključena i pitanja o njihovoj važnosti za ispitanika.

Neke od najpoznatijih takvih mjernih instrumenata sastavili su Cummins (Comprehensive Quality of Life Scale, 1997.), Ferrans i Powers (Quality of Life Index, 1985.), Frisch (Quality of Life Inventory, 1992.), Raphael i sur. (Quality of Life Profile-Adolescent Version, 1996.) (Wu i Yao, 2006.a). Instrumenti su bazirani na pretpostavci da je ukupno zadovoljstvo životom sačinjeno od zadovoljstva pojedinim domenama života i relativne važnosti tih domena koje one imaju za pojedinca. Dakle, za prikupljanje informacije o ukupnoj kvaliteti života, moguće je pomnožiti rezultate zadovoljstva s rezultatima važnosti za svaku domenu života i tek potom pristupiti sumiranju rezultata u ukupan indeks. Izraženo formulom ova ideja glasi:

Subjektivna kvaliteta života $=\Sigma$ (zadovoljstvo domenom $x$ važnost domene $)$.

Primjerice, ukoliko se u istraživanju koristi Lickertova skala od pet stupnjeva, te izraženo zadovoljstvo nekom od domena života iznosi 3 stupnja, a važnost koja joj se pridaje 4, onda bi rezultat za tu domenu iznosio 12 (Trauer i Mackinonn, 2001.). Postupak je potrebno ponoviti za svaku domenu i potom zbrojiti njihove rezultate kako bi se dobio složen subjektivan indeks. Ponderiranje s važnošću je relativno često primjenjivan postupak u formiranju subjektivnoga indeksa kvalitete života, te ga pojedini znanstvenici smatraju ispravnim (Alcazar i Andrade, 2008.; Dzurova i Dragomirecka, 2000.).

Ljudi različito vrednuju različite domene, pa jednostavno zbrajanje zadovoljstva po domenama, bez uključivanja važnosti koja im se pridaje, ne bi moglo adekvatno predstavljati kvalitetu života. Iako se ova ideja čini logičnom, brojna istraživanja pokazala su da je ponderiranje domena s važnosti zapravo nepotreban postupak. Naime, studije su pokazale da ponderirani rezultati ne rezultiraju većom korelacijom s ukupnom kvalitetom života od neponderiranih (Wu i Yao, 2006.b). Odnosno, da ponderirani rezultati ne poboljšavaju predikciju ukupnoga blagostanja, pa je stoga postupak ponderiranja domena suvišan.

Ovu činjenicu primijetili su još pioniri istraživanja subjektivne kvalitete života, Andrews i Withey (1976.) i Campbell, Converse i Rodgers (1976.), no ta spoznaja dugo 
vremena nije bila posve prihvaćena. Naime, Andrews i Withey (1976.) zabilježili su da podaci o važnosti koju ljudi pripisuju pojedinim domenama nisu povećali točnost predikcija o ukupnom iskustvu života.

Trauer i Mackinnon (2001.:580) su, s obzirom da složeni indeks može nastati kombinacijom rezultata koji pokazuju veliko zadovoljstvo, ali malu važnost, te rezultata koji pokazuju nisku razinu zadovoljstva, ali veliku percipiranu važnost, postavili sljedeće pitanje: "Je li je ispravno zaključiti da ove dvije, prilično različite situacije, prikazuju istu 'pravu' razinu kvalitete života?'. U svojem istraživanju pokazali su da ponderiranje domena s važnosti ima minornu ulogu za procjenu ukupne kvalitete života.

Wu i Yao (2006.b) također su došli do zaključka da je multiplikativna metoda nepotrebna, nakon što su testirali različite algoritme ponderiranja korištene za mjerenje kvalitete života koje je konstruiralo nekoliko autora (Cummins, 1997.; Raphael i sur., 1996.; Ferrans i Powers, 1985. te Frisch, 1992.). Cummins (2002.) je nakon višegodišnjega rada na izradi mjernoga instrumenta odustao od ponderiranja zadovoljstva pojedinim područjem s njegovom važnošću za pojedinca. U radu iz 2002. napominje da je od 1997., kada je izašlo peto izdanje priručnika o konstrukciji indeksa subjektivne kvalitete života (Comprehensive Quality of Life Scale, 1997.a), prikupljeno mnogo informacija koje su dovele do novih spoznaja. Njegovo mišljenje slaže se s već navedenima, ali i mišljenjem mnogih drugih znanstvenika da je u postupku stvaranja indeksa kvalitete života množenje zadovoljstva s važnošću, neispravna procedura, te da ne postoji opravdanje za takav postupak.

Trauer i Mackinnon (2001.) smatraju da glavni razlog zašto ponderiranje zadovoljstva s važnošću ne mijenja značajno neponderirane rezultate leži u činjenici da je važnost na neki način već uključena u iskaze o stupnju zadovoljstva. Ispitanici koji navode zadovoljstvo ili nezadovoljstvo nekom domenom time istovremeno pokazuju da ta domena ima određenu važnost za njih. Pogotovo je to slučaj ukoliko iskazuju jako visoku razinu (ne)zadovoljstva. Drugim riječima, ispitanici će izražavati veće nezadovoljstvo ili zadovoljstvo evaluirajući one domene koje su im važnije, nego one koje imaju za njih manju vrijednost.

Iako se načini konceptualizacije kvalitete života često razlikuju među autorima, istraŽivači ipak nastoje uključiti u koncept one dimenzije koje su općenito procijenjene kao važne za većinu ljudi. Dakle, one su a priori izabrane zbog njihove gotovo univerzalne relevantnosti. Stoga, većina domena ima za ispitanike barem djelomičnu važnost (Russell, Hubley, Palepu i Zumbo, 2006.) pa kada ispitanici odgovaraju na pitanja o razini zadovoljstva, u te je odgovore već uključena važnost koju za njih posjeduju navede domene.

Ipak, ukupna kvaliteta života nije ni samo jednostavan zbroj prosječnih zadovoljstva po sastavnim domenama (Rojas, 2006.). Zaključak da je nepotrebno ponderirati zadovoljstvo s važnošću, ne znači da sve domene za sve ljude imaju jednaku vrijednost. Važnost koju ispitanici pridaju različitim aspektima ipak je značajno istraživačko pitanje u razumijevanju kvalitete života. Dapače, podaci o vrijednosti sastavnih 
komponenata blagostanja vrlo su vrijedni u analizi (Wu i Yao, 2006.a; Trauer i Mackinnon, 2001.) i predstavljaju još jedan djelić koncepta, koji dodatno pomaže u njegovoj evaluaciji i objašnjavanju. Podaci o, primjerice, postojanju razlika među različitim grupama ljudi, s obzirom na njihove karakteristike, poput dobi, (ne)hendikepiranosti ili etničkoj pripadnosti, mogu poslužiti za definiranje njihovih prioriteta i pomoći u planiranju usluga koje su im potrebne.

S druge strane, postojeći dokazi da je nepotrebno ponderiranje rezultata zadovoljstva, nose velike prednosti. Zaključak da računanje složenih indeksa nije pravilan postupak, znatno pojednostavnjuje analize kvalitete života. Skraćuje se vrijeme potrebno za dobivanje gotovih rezultata, a i umanjuju moguće greške pri mjerenju. Russel i sur. (2006.) zaključuju da, iako je ovaj način bio vrlo popularan među istraživačima, nove spoznaje eliminiraju potencijalne izvore pogrešaka (pogotovo u slučajevima kada je potrebno računati složene indekse za velike skupove podataka).

Dok se oko pitanja konstrukcije složenih objektivnih indeksa još uvijek debatira, čini se da je rasprava oko ponderiranja subjektivnih pokazatelja, polučila zaključak. Dominantno mišljenje u znanstvenoj zajednici jest da se ukupna kvaliteta života ne može ispravno konceptualizirati kao zbroj zadovoljstva domenama ponderiranih važnošću.

S druge strane, ukupna kvaliteta života ne može se shvatiti ni samo kao jednostavan zbroj zadovoljstva jer je važnost pojedinih domena još uvijek značajan faktor u stvaranju ukupnoga osjećaja zadovoljstva (iako očigledno ne na način da se multiciplira s razinom zadovoljstva).

Stoga, mnogi znanstvenici umjesto da zbrajaju rezultate po domenama kako bi dobili podatak o ukupnoj kvaliteti života, ispitanike izravno ispituju o tome (Lu, 1999.; Parkes, Kearns i Atkinson, 2002.; Oktay i Marans, 2010.; Sereke Tesfazghi, 2009.; Tuan Seik, 2000.; Das, 2008.; Pacione, 1986.; Williams, Kitchen, Randall, i Muhajarine, 2008.; Muhajarine, Labonte, Williams i Randall., 2008.). U tu svrhu primjenjuju se opća pitanja poput: "koliko ste ukupno zadovoljni životom?", "kako biste ocijenili Vašu ukupnu kvalitetu života?’ i sl. Ovako postavljenim izravnim pitanjem izbjegavaju se zamke i nedostaci koje sa sobom nosi računanje indeksa temeljem navedenih postupaka zbrajanja po domenama koncepta.

\section{Zaključak}

O kvaliteti života najčešće se promišlja kao o cjelovitom, složenom konstruktu koji se sastoji od mnogo specifičnih domena. Iz toga razloga postoji i potreba za sumiranjem te prikazivanjem rezultata istraživanja u jednom pokazatelju, odnosno indeksu kvalitete života. Primjena samo jednoga indeksa uvelike jednostavnijim čini usporedbe među mjestima, regijama ili državama, nego što je to usporedba prostora prema nizu pokazatelja koji čine sastavne domene koncepta.

Međutim, u radu je argumentirano da niti jedan način određivanja indeksa na temelju konstruiranih objektivnih i subjektivnih pokazatelja nije idealan i potpuno za- 
dovoljavajući, te da se svaki može osporiti i kritizirati zbog specifičnih manjkavosti. Čak je upitno koliko pojedini indeks vjerodostojno reprezentira cjelokupni koncept. Popularnost indeksa leži prije svega u atraktivnosti ideje da se mnogostruka stvarnost prikaže na jednostavan i razumljiv način, te u poimanju da ljudi ne razdvajaju striktno pojedine komponente života, nego posjeduju jedinstveni osjećaj zadovoljstva životom. No, socijalni fenomeni su vrlo slojeviti, sastavljeni od mreže složenih odnosa koje nije lako analizirati na sistematičan način. Stoga se pojednostavljivanje ovoga koncepata definitivno nije pokazalo kao lak zadatak.

Cilj ovoga rada bio je kritički se osvrnuti na upotrebu jedinstvenih pokazatelja kvalitete života kako bi se skrenula pozornost na brojne probleme i nedoumice s kojima se susreću istraživači prilikom konstrukcije indeksa. Na temelju u radu iznesenih argumenata, odnosno činjenicu da ne postoji konsenzus oko ispravnoga načina agregacije pokazatelja u složeni indeks, može se zaključiti da je upotrebu takvih konstruiranih indeksa bolje izbjegavati. Ukoliko se indeksi ipak primjenjuju, onda je važno da ne budu jedini način na koji su prikazani rezultati analize. Složeni indeksi mnogo se koriste, ali su svakako prikladniji za pregledan prikaz stanja na višim prostornim razinama (npr. država). Umjesto složenih indeksa, moguće je primijeniti neke od alternativnih načina pojednostavljivanja strukture pokazatelja. Primjerice, umjesto indeksa temeljenih na objektivnim pokazateljima, mogu se koristiti skupovi reprezentativnih pokazatelja (eng. key indicators) i višedimenzionalne prezentacijske metode ili opisni profili prostornih cjelina. Umjesto konstruiranja subjektivnih indeksa kvalitete života zbrajanjem rezultata po pojedinačnim domenama, ispitanicima je ispravnije (ujedno i jednostavnije) postaviti izravno pitanje o njihovoj ukupnoj kvaliteti života. Zaključno, može se ponoviti da je bolje izbjegavati primjenu složenih indeksa jer se time umanjuju potencijalni nedostaci koji mogu utjecati na točnost rezultata istraživanja i dovesti do gubljenja detaljnijih informacija o pojedinim aspektima koncepta, kao i do poteškoća oko interpretacije tako dobivenih indeksa.

\section{Literatura}

1. Alcazar, L. and Andrade, R. (2008). Quality of life in urban neighborhoods in Metropolitan Lima, Peru, Inter-American Development Bank, Research Department. Pregledano 12.06. 2013. (http://idbdocs.iadb.org/wsdocs/getdocument. aspx?docnum $=1668608$ ).

2. Andrews, F. M. and Whitney, S. (1974). Developing measures of perceived life quality, in: Michalos Alex (Ed.). Citation classics from Social Indicator Research 2005. Dodrecht: Springer.

3. Australian Unity (2013). What is The Australian Unity Wellbeing Index?. Pregledano 16. 01. 2013. (http://www.australianunitycorporate.com.au/Community/auwi/Pages/whatsAuwi.aspx).

4. Das, D. (2008). Urban Quality of Life: A Case Study of Guwahati. Social Indicators Research, 88 (2): 297-310.

5. Dzurova, D. and Dragomirecka, E. (2000). Quality of life in the Czech Republic. Acta Universitatis Carolinae Geographica, 1: 103-116. 
6. Campbell, A., Converse, P. E. and Rodgers, W. L. (1976). The quality of American life: perceptions, evaluations and satisfactions. New York: Russell Sage Foundation.

7. Cummins, R. (2002). Vale ComQol: Caveats to using the Comprehensive Quality of Life Scale. Welcome: The Personal Wellbeing Index. Pregledano 17.06. 2013. (http://www.deakin.edu.au/dro/view/DU:30030996).

8. Cutter, S. (1985). Rating places, A geographer 's view on Quality of Life, Association of American Geographers. Washington D. C.: Resource publications in geography.

9. Economist Intelligence Unit (2013). The Economist Intelligence Unit's qualityof-life index. Pregledano 14. 06. 2013. (http://www.economist.com/media/pdf/ QUALITY OF LIFE.pdf).

10. Emes, J. and Hahn, T. (2001). Measuring Development, An Index of Human Progress. Pregledano 14. 06. 2013. (http://oldfraser.lexi.net/publications/pps/52/ MeasuringDevelopmentIHP.pdf).

11. Eyles, J. (1994). Social Indicators, Social Justice and Social Well-being, Centre for Health Economics and Policy Analysis (CHEPA), McMaster University, Hamilton, Canada. Pregledano 25.07. 2013. (http://ideas.repec.org/p/hpa/wpaper/199401. html).

12. Genuine Progress (2013). Genuine Progress Indicator. Pregledano 14. 06. 2013. (http://genuineprogress.net/genuine-progress-indicator/).

13. Hagerty, M. R.; Cummins, R. A.; Ferriss, A. L.; Land, K.; Michalos, A. C.; Peterson, M.; Sharpe, A.; Sirgy, J.; Vogel, J. (2001). Quality of Life Indices for National Policy: Review and Agenda for Research. Social Indicators Research, 55 (1): 1-96.

14. Hasan, L. (2007). On Measuring the Complexity of Urban Living. Pregledano 3.10.2013. (http://mpra.ub.uni-muenchen.de/7413/).

15. Human Development Report (1993). Pregledano 12.10. 2013. (http://hdr.undp. org/en/reports/global/hdr1993/chapters/).

16. UNDP (2013). Human Development Index. Pregledano 14.07. 2013. (http://hdr. undp.org/en/statistics/hdi//).

17. Institute for Innovation in Social Policy (2013). Index of Social Health. Pregledano 14.07. 2013. (http://iisp.vassar.edu/ish.html).

18. Kenji Doi; Masanobu Kii and Hitomi Nakanishi (2008). An integrated evaluation method of accessibility, quality of life, and social interaction. Environment and Planning B: Planning and Design, 35 (6): 1098-1116.

19. Knox, P. L. (1974). Spatial Variations in Level of Living in England and Wales in 1961. Transactions of the Institute of British Geographers, 62: 1-24.

20. Knox, P. L. (1978). Territorial Social Indicators and Area Profiles: Some Cautionary Observation. The Town Planning Review, 49 (1): 75-83.

21. Li, G. and Weng, Q. (2007). Measuring the quality of life in city of Indianapolis by integration of remote sensing and census dana. International Journal of Remote Sensing, 28 (2): 249-267.

22. Liu, B. (1976). Quality of life indicators in U.S. metropolitan areas: a statistical analysis. New York: Praeger.

23. Lotfi, S. and Solaimani, K. (2009). An assessment of Urban Quality of Life by Using Analytic Hierarchy Process Approach (Case study: Comparative Study of Quality of Life in the North of Iran). Journal of Social Sciences, 5 (2): 123-133. 
24. Lu, M. (1999). Determinants of Residential Satisfaction: Ordered Logit vs. Regression Models. Growth and Change, 30 (2): 264-287.

25. Malkina-Pykh, I. G. and Pykh, Y. A. (2008). Quality-of-life indicators at different scales: Theoretical background. Ecological Indicators, 8 (6): 854-862.

26. Marans, R. and Couper, M. (2000). Measuring the Quality of Community Life: A Program of Longitudinal and Comparative International Research. Proceedings of the Second International Conference on the Quality of Life in Cities. National University of Singapore, Singapore.

27. Massam, B. H. (2002). Quality of life: public planning and private living. Progress in Planning, 58 (3): 141-227.

28. Morris, A.; Findlay, A. and Rogerson, R. (1988). In search of an explanation of quality of life in British cities: some Scottish dimensions. Scottish Geographical Magazine, 104 (3): 130-137.

29. Muhajarine, N.; Labonte, R.; Williams, A.; Randall, J. (2008). Person, Perception, and Place: What Matters to Health and Quality of Life. Social Indicators Research, 85 (1): 53-80.

30. OECD (2008). Key environmental indicators. Pregledano 12.09. 2013. (http:// www.oecd.org/dataoecd/20/40/37551205.pdf).

31. OECD (2013). Better Life Index. Pregledano 12.09. 2013. (http://www.oecdbetterlifeindex.org/about/better-life-initiative/).

32. Oktay, D. and Marans, R. (2010). Overall quality of urban life and neighborhood satisfaction. Open House International, 35 (3): 27-36.

33. Pacione, M. (1982). The use of objective and subjective measures of life quality in human geography. Progress in Human Geography, 6 (4): 494-514.

34. Pacione, M. (1986). Quality of life in Glasgow: an applied geographical analysis. Environment and Planning A, 18 (11): 1499-1520.

35. Parkes, A.; Kearns, A. and Atkinson, R. (2002). What Makes People Dissatisfied with their Neighbourhoods?. Urban Studies, 39 (13): 2413-2438.

36. van Poll, H. (1997). The perceived quality of the urban residential environment: a multi-attribute evaluation. Pregledano 20.09. 2013. (http://dissertations.ub.rug. nl/FILES/faculties/science/1997/h.f.p.m.van.poll/thesis.pdf).

37. Rogerson, R. (1999). Quality of Life and City Competitiveness. Urban Studies, 36 (5-6): $969-985$.

38. Rojas, M. (2006). Life satisfaction and satisfaction in domains of life: is it a simple relationship?. Journal of Happiness Studies, 7 (4): 467-497.

39. Russell, L.; Hubley, A.; Palepu, A.; Zumbo, B. (2006). Does Weighting Capture What's Important? Revisiting Subjective Importance Weighting with a Quality of Life Measure. Social Indicators Research, 75 (1): 141-167.

40. Savageau, D. (2007). Places Rated Almanac: The Classic Guide for Finding Your Best Places to Live in America $7^{\text {th }}$, Washington D.C.: Places Rated Books, LLC.

41. Sawicki, D. S. and Flynn, P. (1996). Neighborhood Indicators: A Review of the Literature and an Assessment of Conceptual and Methodological Issues. Journal of the American Planning Association, 62 (2): 165-183.

42. Sereke Tesfazghi, E. (2009). Urban quality of life and its spatial distribution in Addis Ababa: Kirkos sub-city. Pregledano 10.08. 2013. (http://www.itc.nl/ library/papers_2009/msc/upm/tesfazghi.pdf). 
43. Sharpe, A. (1999). A Survey of Indicators of Economic and Social Well-being. Pregledano 15. 10. 2012. (http://www.csls.ca/reports/paper3a.pdf).

44. Smith, D. (1973). The geography of social well-being in the United States an introduction to territorial social indicators. New York: McGraw-Hill.

45. Smith, D. (1996). The quality of life, Human welfare and social justice, in: Douglas Ian; Hugget Richard and Robinson Mike (Eds.). Companion Encyclopedia of Geography. London: Routledge.

46. Smith, D. (1979). The identification of problems in cities: Applications of social indicators, in: Herbert David and Smith David (Eds.). Social problems and the city, Geographical perspectives. Oxford: Oxford University Press.

47. The Social Progress Imperative (2013). Social Progress Index. Pregledano 20.06.2013. (http://www.socialprogressimperative.org/data/spi/methodology).

48. Trauer, T. and Mackinnon, A. (2001). Why are we weighting? The role of importance ratings in quality of life measurement. Quality of Life Research: An International Journal of Quality of Life Aspects of Treatment, Care and Rehabilitation, 10 (7): 579-585.

49. Tuan Seik, F. (2000). Subjective assessment of urban quality of life in Singapore (1997-1998). Habitat International, 24 (1): 31-49.

50. UIC, Quality of life indeks. Pregledano 10.6.2013. (http://www.uic.edu/orgs/ qli/).

51. United Nations (2007). Indicators of sustainable development: guidelines and methodologies. $3^{\text {rd }}$. New York: United Nations. Pregledano 28.11. 2013. (http:// www.un.org/esa/sustdev/natlinfo/indicators/guidelines.pdf).

52. Ülengin, B.; Ülengin, F.; Güvenç, Ü. (2001). A multidimensional approach to urban quality of life: The case of Istanbul. European Journal of Operational Research, 130 (2): 361-374.

53. Van de Ven, P.; Kazemier, B. and Keuning, S. (1999). Measuring well-being with an integrated system of economic and social accounts. Pregledano 23.10. 2013. (http://www.cbs.nl/nr/rdonlyres/a6d5f2de-754f-4b44-8d00-1213ac38c7a2/0/ wellbeing def.pdf).

54. Williams, A.; Kitchen P.; Randall, J.; Muhajarine, N. (2008). Changes in quality of life perceptions in Saskatoon, Saskatchewan: comparing survey results from 2001 and 2004. Social Indicators Research, 85 (1): 5-21.

55. Wong, C. (2006). Indicators for Urban and Regional Planning. London: Routledge.

56. The World Bank (2013). Gini Indeks. Pregledano 28.09. 2013. (http://search. worldbank.org/all?qterm=gini\%20index).

57. Wu, C. and Yao, G. (2006a). Do We Need to Weight Item Satisfaction by Item Importance? A Perspective from Locke's Range-Of-Affect Hypothesis. Social Indicators Research, 79 (3): 485-502.

58. Wu, C. and Yao, G. (2006b). Do We Need to Weight Satisfaction Scores with Importance Ratings in Measuring Quality of Life?. Social Indicators Research, 78 (2): 305-326.

59. Zebardast, E. (2009). The Housing Domain of Quality of Life and Life Satisfaction in the Spontaneous Settlements on the Tehran Metropolitan Fringe. Social Indicators Research, 90 (2): 307-324. 


\title{
Lana Slavuj
}

University of Zagreb, Faculty of Science, Department of Geography, Croatia

e-mail: lslavuj@geog.pmf.hr

\section{Issues of Derivation of Composite (Objective and Subjective) Indices as Integral Measures of the Quality of Life Concept}

\begin{abstract}
This paper deals with the issues of derivation of composite (objective and subjective) indices as integral measures of the quality of life concept. Integration of a large number of indicators into one index is an intriguing idea that makes an important part of the quality of life research. It is based on the presumption that people do not isolate particular aspects of their life, but have an integral feeling of life satisfaction. This is also one of the most controversial parts of the quality of life research because the way in which indices are aggregated is subject to numerous criticisms. Studies show that it is not easy to construct an index that is complete enough and which unambiguously includes all aspects of the individual and collective quality of life. Although quality of life indices are commonly used (especially for the presentation of results on national levels and for comparison among various countries), present experiences show it is more appropriate to replace them with a non-aggregate set of objective indicators or with a direct question about the individual overall quality of life.
\end{abstract}

Key words: quality of life indices, objective indicators, subjective indicators, weighting indicators. 